States, are prepared as well to offer Israel meaningful supplementary commitments and "guarantees" to accompany an overall settlement to insure Israeli security.

At least Israel should be seriously considering the alternatives to the status quo, which offers little hope but for continual, more devastating conflict. False historical parallels and selfserving appeals to morality over politics are not reasonable substitutes for historical honesty, creative diplomacy, and a vision of recunciliation.

\section{New Testament Pacifism}

To the Editors: Re: James T. Johnson's "Just War Theory: What's the Use?" (Worldview, July-August). Johnson renders a needed service by pleading for an ethical process to examine problematic areas of human experience in order " to inform conceptions of national interest. " He also seems right in pointing out our failure "to relate values to political realities today. "I agree with Johnson that there are worse things than war, but let that not become a justification for war.

Johnson disposes of the New Testament pacifist a little too easily. The differences are theological rather than "a dispute between realists and utopians. "He says: "to put the difference more starkly, pacifists look to God's saving them from this world, while just war theorists look to how they can cooperate with God in redeeming this world through love." I disagree. There are New Testament pacifists who care deeply about the world, identify with the world in its pain and struggle, see God at work in it and joyfully join in God's action. Their position is a far cry from a "laissez faire attitude toward this world because they place their faith utterly in the lordship of God, understood as manifest in condemnation of the $\sin$ of this aeon."

Professor of Psychology

Atlee Beechy

Goshen College

Goshen, Ind.
James T. Johnson Responds:

Whenever generalizations are made there are always exceptions. I will not therefore dispute Professor Beechy's claim that New Testament pacifists exist who "care deeply about the world," etc. In fact, it is quite possible that one of the problems preventing meaningful dialogue between pacifists and just war theorists in the past has been misunderstanding of the theological stance of those on the other side. I hope there are such pacifists as Beechy believes exist, because 1 can see them participating in such dialogue, and I can hope that they and just war theorists might accomplish more than to clarify their differences.

Again, I think such dialogue might focus on the "original question," whether it is ever justified for a Christian to take part in war. It is little remembered that pacifists participated in the fashioning of just war doctrine in the Middle Ages; yet it is arguable that without a significant peace movement there would never have been promulgated the Truce of God, the Peace of God, and the weapons ban of Lateran II. We today might well, therefore, attempt to overcome the division between "utopian" and "realist" positions that has bedeviled constructive political ethics since Niebuhr. I think Beechy will admit that my article presents terms like these as part of the problem, and that both pacifists and just war theorists who take their guidance from Christian faith might best investigate their theological differences instead, as a starting-point for reviving political ethics.

\section{African Religions}

To the Editors: Readers of Dr. John Mbiti's vitriolic review of my book, African Religions: Symbol, Ritual, and Community (Books: Worldview, June), must have wondered at the underlying source of his animus, and may well have questioned the judgment of the editors in publishing such a "hack" review. Surely it says more about Dr. Mbiti's personal opinions than it does about the book. Too bad for your readers!

Dr. Mbiti's attack appears to be aimed at the book's methodological consistency and at the author's credentials for writing it. Thus while the book professes to be an in-depth analysis of religious themes among a limited number of African societies, it is charged with being a haphazard collection of "illustrations," loaded with superficial generalizations. In fact the book is a closely integrated, contextual discussion, organized around a core group of fifteen societies, with a few others added for balance and comparison. The qualitative difference between this kind of treatment and the books written by $\mathrm{Dr}$. Mbiti (African Religions and Philosophy and Concepts of God in Africa), each claiming to cover nearly three hundred different societies, will be obvious to anyone.

As for my scholarly credentials, Dr. Mbiti tries to suggest that the book was written on the basis of a brief period of fieldwork in Uganda in 1972. This is patently absurd. Only a fraction of it draws upon this research (which, incidentally, was conducted in a Ugandan language that Dr. Mbiti, a Kenyan now living in Switzerland, does not understand, though he resided in this part of Uganda for several years).

The bulk of the book is based upon authoritative anthropological studies, including several by African scholars, which I am professionally equipped to handle. The situation could hardly be otherwise, for anyone (African or European) writing about more than one or two societies is compelled by linguistic differences and by limitations for fieldwork to rely upon the work of others. In fact Dr. Mbiti chooses many of these same authorities for his own work.

But unlike his own publications, the present book offers a balanced and critical discussion of various interpretations and perspectives on African religions, including Dr. Mbiti's, and stresses the significant role which the study of African religions has played in Western scholarship. All of this Dr. Mbiti dismisses as lacking in "serious academic help," despite the introductory purpose of the book. In a sense Dr. Mbiti is right in saying that the book presents a variety of "readings," for its purpose is to introduce students to the rich and complex texture of African religions. It does not try to force these materials into a Western theological mold, which is what passes for "systematic" study in Dr. Mbiti's mind, nor does it assume, as Dr. Mbiti does, that there exists one underlying African "religion" derived 
from the revelation of the JudeoChristian God.

Two comments in particular show that Dr. Mbiti has great difficulty in reading the book. One is the accusation that it indulges in "frequent comparison of African religious life with that of the West," whereas there is not one instance of this in the whole work. The other is that it slights African notions of supreme being, to which in fact lengthy and substantial discussion is given.

The real point of Dr. Mbiti's attack and the underlying source of his discontent lies in his statement concerning "foreigners" who write about African religions with an anthropological "bias." These are indeed important points, especially when made in a journal devoted to international affairs and to intellectual dialogue

Like many of his clerical colleagues, who belong to the colonially derived churches, Dr. Mbiti is engaged in the important and demanding task of indigenizing Christianity in Africa. Unfortunately he sees Western secular scholarship as his chief enemy. But this is hardly the case. The main opposition comes from the large body of conservative African Christians who wish to retain many irrelevant Western liturgical and ecclesiastical forms. A different kind of challenge comes from the growing number of Independent Churches in Africa that have already made new and creative syntheses of Christianity and African tradition. A few of these churches are now members of the World Council of Churches, and they often draw people away from the more conservative European-founded churches.

Instead of pushing ahead with new liturgical and theological innovations, Dr. Mbiti and others have chosen a more gradual and perhaps more productive course. They have sought to develop a new African theology by discovering parallels to Christianity in African traditional religions, thereby gaining theological insight into their own traditional culture. Thus they find African notions of supreme being to be rooted in the monotheistic idea of God, and they see corresponding notions of $\sin$, afterlife, and divine judgment.

No one would deny that this is a properly theological endeavor, and one which must be carried out by Africans themselves. The question is not a matter of "foreigners" versus Africans, as Dr. Mbiti would like to think, but of differ- ent tasks, one secular and humanistic, the other theological and evangelical. This has already been pointed out to Dr. Mbiti by many African scholars. These different concerns have long been engaged in fruitful dialogue, and one would hope that they would continue to do so in relation to African religions. Dr. Mbiti only demeans himself and the wider discussion by resorting to the level of personal diatribe.

Department of Religion

Benjamin C. Ray

Princeton University

Princeton, N.J.

John Mbiti Responds:

The editors have kindly invited me to reply to Professor Benjamin Ray's letter concerning my review of his book, African Religions: Symbol, Ritual, and Community. I take note of his personal attack on me simply because 1 dared criticize certain aspects of the book the author so generously praises. I do not wish to retaliate. If this book is faultless, it will certainly speak for itself, in keeping with a Swahili proverb that says: Chema chajiuza, kibaya chajitembeza ("a good article sells itself, a bad article roams about looking for customers'").

Your readers will be impressed, as I am, by Professor Ray's linguistic abilities, which enabled him to conduct research, as he claims, "in a Ugandan language," when he stayed in Uganda for only a few months!

Let me take up only one academic point. Professor Ray denies in this letter that he made comparison of African religious life with that of the West. Some quotations from his own book will remind him of what he seems to have forgotten. Page 5: "No matter how 'value-free' these concepts may be, they still characterize Africa as the opposite of the West and thus reinforce a negative perspective." Page 14: "Thus they reduce African religions to a set of 'doctrines' analogous in structure to Western faiths...." Page 74: "Like advice columnists in Western newspapers, Ashanti mediums dole out much needed moral and religious counsel..." Page 132: " Until recently, Western scholars have failed to appreciate the extent to which African religions are founded upon a systematic anthropology and ethics....It never approximates the Western notion of individualism...."
Page 150: "Unlike Western religions, African thought does not conceive the source of evil to be.....

I feel sympathetically amused if and when a scholar denies what he has written and published in his own book. Therefore it becomes difficult to take him or her seriously. If I had the space and the interest, I could certainly produce enough evidence to counteract the other statements made in Dr. Ray's letter.

My dear friend Dr. Ray, if and where I may wrongly have criticized your book, please forgive me and put me right without using the occasion to pile up personal attacks on me. (I also made points of appreciation about it, mind you!) You once weicomed me at your University in 1970; and I was very happy to reciprocate your kindness by arranging for you to spend a few months as visiting professor at Makerere University in 1972. I have no personal quarrels with you. Please use your brilliant mind much more for academic good than for personal attacks on people who are or have been your colleagues. There is enough territory for you and these colleagues to engage in academic pursuits-with sufficient differences of opinion and approach, which add to the value of academic dialogue. Such a dialogue is killed when one person attacks viciously others who dare make a few critical points about that person's publications.

\section{Lebanon}

To the Editors: My own position is that it is outrageous and pejorative to label-perhaps libel-the Christian Lebanese as "right wing," and the Moslem Lebanese as "left wing" (see Barry Rubin's discussion of the issue in an Excursus. "Misunderstanding Lebanon," in the June issue of Worldview). In terms of Western European democratic values, the Christian Lebanese are certainly more "liberal" than the Moslem Lebanese.

It would be correct to characterize the Christian Lebanese as more economically privileged than the Moslem Lebanese. That assessment, however, should not permit the designation of these parties as right and left wing. In fact, the Moslems have what must be 